\title{
Innovative Learning Material with Project to Improve Students Achievement on the Teaching of
}

\section{Acid-Base Equilibrium}

\author{
Sanhot Simaremare \\ Study Program of Chemistry Education, \\ Universitas Negeri Medan, \\ Medan, Indonesia, 20221, \\ sanhotsimaremare16@gmail.com
}

\author{
Manihar Situmorang \\ Department of Chemistry \\ Universitas Negeri Medan \\ Medan, Indonesia, 20221, \\ msitumorang@unimed.ac.id
}

\author{
Simson Tarigan \\ Study Program of Chemistry Education, \\ Universitas Negeri Medan, \\ Medan, Indonesia, 20221
}

\begin{abstract}
Implementation of competence-based curriculum for Chemistry become a strategy to pulfil an Indonesian National Qualifications Framework (Kerangka Kualifikasi Nasional Indonesia, KKNI), and therfore it needs to apply active learning through project to provide the students with appropriate knowledge and skills on the subject they learn. This study is aimed to provide an innovative chemistry learning material to be used as learning media on the teaching of acid-base equilibrium. The research is carried out through innovation of learning material with project followed by the integration of multimedia into a learning package to meet the national standard requirement. The developed learning material was then be implemented as a guide material for students to complete the projects during the teaching and learning activities. Research results has showed that sets of standard projects on acid-base equilibrium topic have successfully provided that were integrated in the textbook suited to the university curriculum. The complete and innovative learning package has been designed with multimedia. It has been proved that a package of innovative learning material has been found to be effective to be used to help students to learn analytical chemistry. Students' learning style has been changed to become independent learning. The students are enthusiasm to do the given projects and improve their achievement on chemistry. An innovative learning material are able to guide the students to learn and to improve their knowledge and skill to meet required competence needed in the KKNI curriculum.
\end{abstract}

Keywords-Learning innovation, project based learning, Students competence, acid-base equilibrium

\section{INTRODUCTION}

The commitment to implement competence based curriculum suited to the National Qualifications Framework (in Indonesian Kerangka Kualifikasi Nasional Indonesia, KKNI) requires improvement in the teaching and learning activities toward outcomes based learning in accordance to the learning purposes. One of the strategy to be done to improve students achievements is through using innovation of learning material that can be used in the teaching and learning activities. An innovative learning material is account to be a very good tools to be used to attract students attention and motivation to improve their learning potential as it can be used as learning resources to develop their knowledge and skills. The compatibility of learning material with technology becomes an addition value to be exploited to adjusted with students developments and the reality in a globalized era [1-3]. Innovative learning material can be adopted as a media in chemistry teaching with purposes to make the abstract and complex process that commonly found in the chemical reaction can be visualized into real and simple mode that can enhance the learners understanding on chemistry [4-6]. The development of an innovative chemistry teaching materials for chemistry teaching has become attention recently to guide the learners become active learning [7-9]. An innovative learning material with multimedia has been applied in chemistry learning [10-12]. It has been known that an innovative learning materials using multimedia enhance students understanding on chemistry and it can be utilized with elearning for learning through online facilities to facilitate the learner for independent study $[13,14]$.

Teaching and learning activities with project is a very good strategy to connect the theory with real world and can bring the students engaged in active learning [15-17]. A learning model of project based learning (PBL) has been implemented in science teaching [18]. With the PBL, the students can explore their knowledge in the structured and complex processes, synthesis and results in deep understanding on the target topic through learning activities [19]. The project that has been designed systematically can be used to develop students knowledge and skills on specific affective target [20]. With this reason, an effort has been made in this study to innovate teaching and learning materials to be used to improve students achievement on analytical chemistry. Through project, the students achieve the skills on product oriented learning since they are involved personally in planning a project, working on a project, and reporting of the results from the project. Active learning with project motivated the students to learn, facilitate the learner to work together and results in deep understanding on the subject $[21,22]$. An innovative learning materials are very important for students to make the students be interested to study chemistry. Innovative learning materials will help the students 
to understand the concept of achieving desired desires be easy and repeatable [23]. The study is aimed to develop an innovative learning material with project to be used as a learning media to improve students achievement on the teaching of Acid-Base Equilibrium. An innovative learning materials containing of sets of projects that was interfaced with multimedia can motivate the students to become active learners and results on improving their knowledge and skills which is expected to improve students' achievements on chemistry.

\section{RESEARCH METHOD}

The study is assigned to be a research and development scheme with involving the development of innovative learning material and be implemented in the class on experimental setting. The study consisted of three schemes, the development of an innovative learning material with projects, standardization of the sets of learning material, and implementation of the learning package followed the procedures explained in the references [24-26]. An innovative learning material with projects was prepared for Acid-Base Equilibrium topic starting from enriching the topic with contextual examples and designed to becomes sets of mini projects, followed by integration of the material with multimedia. Standardization of the learning package was carried out by evaluating of the materials by experts followed by tryout to obtain standard material for Acid-Base Equilibrium by using the procedures described in previous studies [27].

Implementation of the developed material was done in experimental class and compare with conventional teaching. Before the teaching treatment is carried out a pre-test is given to students to investigate the students knowledge on the subject they learn as well as to homogenize the samples. Sets of innovative learning materials with projects were given to students in experimental class while the students in control are given ordinary textbook. The students both in experiment and control class are given the same topic of Acid-Base Equilibrium topic but with having flexibility for students optimizing their study learning and to use laboratory facilities to conduct their study with time arrangement with laboratory staffs. The sudents are allowed to work together three to four persons in a group to complete the projects in experimental class and to do practicum in control class, but the reports are submitted as personal report. The students extend their group to discuss the subject they learn, including to answer given questions that are available for every sub topic of Acid-Base Equilibrium. Students performances on psychomotor are obtained by observer from their academic activities during their working study and from submitted reports.

\section{RESEARCH RESULTS AND DISCUSSION}

\section{Innovative learning material with project}

An innovative learning material on Acid-Base Equilibrium has been developed for undergraduate study that was suited to the KKNI curriculum. The subjects consisted of six sub subject, they are Introduction to Acid-Base Equilibria, Definition of Acid-Base, Water Ionization, Acid-base Ionization, Determine $\mathrm{pH}$, and Buffer solution [28] Various components are integrated in learning package as summarized in Table 1.

TABLE 1: Description of Sub-Topic and the components that are integrated in the learning material of Acid-Base Equilibria.

\begin{tabular}{clll}
\hline No & \multicolumn{1}{c}{ Sub-Topic } & \multicolumn{1}{c}{ The components that are Integrated into learning material } \\
\hline 1 & $\begin{array}{l}\text { Introduction } \\
\text { Acid-Base }\end{array}$ & to & $\begin{array}{l}\text { Enrichment of teaching materials, integration of learning projects as student activities, pictures, illustrations of } \\
\text { the role of acid base in daily life, and some basic questions about acid-base material. }\end{array}$ \\
2 & $\begin{array}{l}\text { Definition of acid- } \\
\text { base }\end{array}$ & $\begin{array}{l}\text { Enrichment of teaching materials, integration of learning projects as student activities, several chemical } \\
\text { scientists, pictures, chemical info, and several questions that students will answer based on reference and } \\
\text { laboratory activities. } \\
\text { Enrichment of teaching materials, integration of learning projects as student activities, pictures, chemical info, } \\
\text { sample questions and discussion and practice questions. Enrichment of teaching materials, integration of } \\
\text { learning projects as student activities, pictures, chemical info, sample questions and discussion, practice } \\
\text { questions, several questions related to the project } \\
\text { Enrichment of teaching materials, integration of learning projects as student activities, chemical info, pictures, } \\
\text { sample questions and discussions, practice questions, special practice questions, and several questions related to } \\
\text { the project. } \\
\text { Enrichment of teaching materials, integration of learning projects as student activities, case of determining pH } \\
\text { of acid and base buffers, examples of questions and discussion, practice questions, special practice questions, } \\
\text { and several questions related to the project. } \\
\text { Components Integrated into Innovative Teaching Materials in Teaching Acid-Base Equilibrium }\end{array}$ \\
& $\begin{array}{l}\text { Acid-base } \\
\text { ionization }\end{array}$ & Determine pH &
\end{tabular}

All subtopics are enriched with contextual examples suited to undergraduate curriculum major in science. The developed materials are integrated with sets of mini projects, laboratory worksheet, supporting videos, learning methods and models, and learning multimedia. Integration of the projects and laboratory activities are made to guide the students to learn the topic and bring the students in to the application of the subjects they learn in real life. Learning methods such as demonstration methods, training methods, practical methods and work discussion are also included in the learning materials to make the students more active that lead them to various 
learning skills to enhance students understanding on the AcidBase Equilibria.

To improve the feasibility of developed learning material as learning resource to study Acid-Base Equilibria, multimedia was then integrated in to the packaged through combining the images, graphics, animated videos and demonstration videos as presented in Table 2. Multimedia integration in this teaching material aims to make acid-base equilibrium material more practical to learn so that students more easily understand acid-base equilibrium material and are interested in studying chemical material especially in acidbase equilibrium material (learning independently). Sets of projects has been designed for sub-subject of Acid-Base Equilibria with aimed to improve students competence in Analytical Chemistry. The title, short description of the projects and the competency to achieved from conducting the projects are summarized in Table 3 . The projects are mostly conducted in the laboratory with intention to bring chemistry into real learning that can motivate the students to study chemistry.

TABLE 2: Description of components that are integrated into Innovative Learning Materials use the Project using Multimedia

\begin{tabular}{cccc}
\hline No & Sub- Subject & \multicolumn{2}{c}{ Component Innovation } \\
\hline 1 & $\begin{array}{l}\text { Introduction to } \\
\text { Acid-Base }\end{array}$ & $\begin{array}{l}\text { Laboratory experiment video, flash } \\
\text { animation }\end{array}$
\end{tabular}

2 Definition of acid-base

3 Water Ionization

4 Acid-base ionization

6 Buffer solution
Laboratory experiment video, flash animation, website about acid-base explanation

Laboratory experiment video, flash animation, website about explanation of water ionization, and power point learning media.

Laboratory experiment video, flash animation, website about acid-base ionization, website about access to practice questions, and power point learning media which ends with a quiz

Laboratory experiment video, flash animation, website about acid-base ionization, website about access to practice questions, and power point learning media which ends with a quiz

Laboratory experiment video, flash animation, website about acid-base ionization, website about access to practice questions, website about access to practice questions, and power point learning media which ends with a quiz

TABLE 3: Type of projects and the competence to achieve in sub-subjects of Acid-Base Equilibrium topic

\begin{tabular}{|c|c|c|c|}
\hline No & Sub- Subject & Project title & Competencies that are expected to be achieved by students \\
\hline \multirow[t]{2}{*}{1.} & \multirow[t]{2}{*}{$\begin{array}{l}\text { Introduction } \\
\text { to Acid-Base }\end{array}$} & $\begin{array}{l}\text { Project } 1 \text { is an experiment in } \\
\text { laboratory with the title "pH } \\
\text { I Scale: Determining the } \mathrm{pH} \\
\text { of Food and Beverages and } \\
\text { Some Chemicals" }\end{array}$ & $\begin{array}{l}\text { 1. Students understand at designing experiments on determining the } \mathrm{pH} \text { of food and } \\
\text { beverages and some chemicals } \\
\text { 2. Students understand in choosing the tools and materials used in this experiment } \\
\text { 3. Students understand time management during practicum } \\
\text { 4. Students understand in preparing observations } \\
\text { 5. Students understand in classifying food and beverages and some food and } \\
\text { beverage ingredients based on pH prices (research report). }\end{array}$ \\
\hline & & $\begin{array}{l}\text { Project } 2 \text { is an observation of } \\
\text { theoretical activities with the } \\
\text { title "pH II Scale: } \\
\text { Submicroscopic } \\
\text { Determination of the pH of } \\
\text { Food or Beverages }\end{array}$ & $\begin{array}{l}\text { 1. Able to choose several references (books, journals, articles etc.) that support the } \\
\text { determination of pH scale. } \\
\text { 2. Able to identify the results of the research / core presented in the reference. } \\
\text { 3. Able to prepare research reports. }\end{array}$ \\
\hline \multirow[t]{2}{*}{2.} & \multirow[t]{2}{*}{$\begin{array}{l}\text { Definition of } \\
\text { acid-base }\end{array}$} & $\begin{array}{l}\text { Project } 3 \text { is an experiment } \\
\text { laboratory laboratory } \\
\text { activities with the title } \\
\text { "Determination of } \mathrm{pH} \\
\text { through the Modern } \\
\text { Arrhenius Acid Base } \\
\text { Theory" }\end{array}$ & $\begin{array}{l}\text { 1. Students understand designing electrolyte test equipment } \\
\text { 2. Students understand choosing and using the complete tools and materials used in } \\
\text { this experiment } \\
\text { 3. Students understand preparing research reports } \\
\text { 4. Students understand the pH of some substances through modern Arrhenius acid- } \\
\text { base theory. }\end{array}$ \\
\hline & & $\begin{array}{l}\text { Project } 4 \text { is an experiment } \\
\text { laboratory activities with the } \\
\text { title "Determination of } \mathrm{pH} \\
\text { through the Theory of } \\
\text { Bronry Lowry and Lewis } \\
\text { Base Acid" }\end{array}$ & $\begin{array}{l}\text { 1. Students understand designing experiments to find out the differences between } \\
\text { Bronsted Lowry acid-base theory and Lewis acid-base theory } \\
\text { 2. Students understand choosing and using the complete tools and materials used in } \\
\text { this experiment } \\
\text { 3. Students understand preparing research reports } \\
\text { 4. Skilled in determining the pH of some substances through Bronsted Lowry and } \\
\text { Lewis acid-base theory. }\end{array}$ \\
\hline
\end{tabular}


3. Water Ionization

Project 5 is an experiment laboratory activities with the title "Water Ionization Equilibrium"

\section{Acid-base}

Project 6 is an experiment ionization laboratory activities with the title "Ionization of Acid and Bases"

\section{Determine $\mathrm{pH}$}

Project 7 is an experiment laboratory activities with the title "Determining the $\mathrm{pH}$ of Acid-base Solutions"

\section{Buffer solution}

Project 8 is an experiment laboratory activities with the title "Acidity Control Buffer Solution"
1. Students understand designing an electrolytic test equipment for electrical conductivity of chemicals

2. Students understand thinning concentrated acids and bases and determining their concentration

3. Students understand the preparation of observation tables of acid and base electrolyte flame tests at various concentrations

1. Students understand at designing an electrolyte test equipment for electrical conductivity of various predetermined acids and bases.

2. Students understand in diluting the determined concentrated acids and bases $(\mathrm{HCl}$, $\mathrm{HF}, \mathrm{NaOH}, \mathrm{NH}_{3}$ ) to obtain the same concentration as needed

3. Students understand in testing and comparing electrical conductivity of materials at the same concentration.

4. Skilled in the preparation of tables observing the flame test of the acid and base electrolytes used.

5. Skilled in preparing research reports.

1. Students understand to makes natural indicators of natural materials.

2. Students understand in designing experiments to distinguish acidic properties or alkaline properties of chemicals by using natural indicators.

3. Students understand to identify and use the right tools and materials.

4. Students understand in time management adjustments.

5. Students understand in presenting data on research results and preparing reports

1. Students understand in choosing tools and materials that can be used in the work of buffer solutions in the body

2. Students understand in designing experiments to obtain a working description of the buffer system in the body

3. Students understand to identify and use tools and materials appropriately.

4. Students understand in time management adjustments.

5. Students understand in presenting data on research results and preparing reports
Standardization of a developed innovative learning materials have been used followed the criteria given by the National Education Standards Agency (BSNP). It has been obtained that the feasibility of the material is categorized very good (average 3.59). All respondents gave positive response to the learning package in all components of content, language, presentation, and graphic. Therefore, an innovative learning material with project has meet the criteria given by national standard as a learning resource on the teaching of Acid-Base Equilibrium

\section{Implementation of Innovative learning Material}

Implementation of an innovative learning materials have been done in the class, where students achievement in pretest and post-test are summarized in Table 4. It has been seen that the students in experimental and control class are having the same starting knowledge on Acid-Base Equilibrium topic (M $=32.5$ ). Students achievements are increased after teaching and learning activities are carried out, where experimental class $(\mathrm{M}=82.5)$ are higher than control class $(\mathrm{M}=75.27)$. It has been observed from students activities, it was known that the students in the experimental class are enthusiastic to do the projects, each group was seriously participate in the discussion and they are tend to use the developed learning material as the main learning resources to solve all problems on the subject they learn.
TABLE 4: Students' achievement based on evaluation test (pre-test and posttest)

\begin{tabular}{lccc}
\hline \multirow{2}{*}{$\begin{array}{c}\text { Treatment } \\
\text { Class }\end{array}$} & \multicolumn{2}{c}{ Type of Evaluation test } & \multirow{2}{*}{$\begin{array}{c}\text { Effectivity } \\
(\%)\end{array}$} \\
\cline { 2 - 3 } & Pre-Test & Post-Test & \\
\hline Experiment & 32.5 & 82.5 & 77 \\
Control & 32.5 & 75.27 & 64
\end{tabular}

The students reported the project results on time in a good laboratory report. Meanwhile, the students in control class seems to do laboratory experiments as a routine works, where the students just follow the experiments listed in the laboratory manual, record the data, and write the report without deep understanding on the subjects they learn. The results has shown that the students in experimental class improve their knowledge and having good understanding on the concept of Acid-Base Equilibrium. The student learning outcomes in the experimental class are all obtain relatively highest score compare to students in control class with variation in the students achievement, where fiew are having high score and most of them are with average score. The projects have also designed to students skills to handle chemicals, instrumentation and chemical analysis. To guide the students to do the project properly, the developed learning material has provided the video on how to use analytical glassware and equipments, the preparation of analytical reagents, examples of laboratory works, and how to record and analyze data by using related software. Observation has revealed that the students in experimental class master themselves in analytical 
chemistry skills as presented in table 5. The motivation of students to study chemistry has been investigated for experimental class. It has been showed that the students motivation such as challenge, curiosity, engagement, confidence, attention, relevance, satisfaction are generated by the presence of an innovative learning material. The facilities integrated in an innovative learning material help the students to study chemistry and shifted learning activities to become student center learning. The results have showed that the required competencies have been achieved.

TABLE 5: Students skills after implementation of acid-base balance projects

\begin{tabular}{ll}
\hline No & \multicolumn{1}{c}{ Observation of Competency Analysis } \\
\hline 1 & The students are able to set the equipment, to standardize the instrumentation, and to prepare experimental steps in good o \\
2 & The students have skills to prepare reagents and standard solution at a certain concentration from stock chemicals (solid or liquid) by \\
weighing and diluting in volumetric flask, and transferred with volume pipettes
\end{tabular}

\section{Discussion}

Implementation of an Indonesian National Qualifications Framework (Kerangka Kualifikasi Nasional Indonesia, KKNI) as based curriculum in Universitas Negeri Medan [29] has prompted the chemistry teaching, including Analytical Chemistry, to promote students competence in the subject they learn [30]. Teaching and learning activities by using of an innovative learning material with project has been proven to be a suitable strategy to improve students achievement in chemistry [31]. Analytical chemistry course as a compulsary subject in science has to be contributed to improve students competences as required in the curriculum [32,33]. The project based learning is a choise method that can improve students involpment in learning activity that leads the students to achieve skills and knowledge in cemistry. It has been proven in this study that a set of innovative learning material with project has bring the students to become independent learner [34,35].

The students has used a developed learning material as a main source to do the projects on their own style to achieve the setting goals given for Acid-Base Equilibrium topic. The projects that are integrated in the learning material has bring the students to study the chemistry topic in dept learning where the theory has been made to become practice and make the students understand an abstract concept that commonly occurs in chemistry subject. An innovative learning material has a positive impact to students learning process where the students are motivated to do the projects that resulting in improving the skills and knowledge [36]. Students achievement in experimental class was higher than that in control class. The results confirmed that an innovative learning material developed in this study is effective to improve students achievement in chemistry.

\section{CONCLUSION}

The development of an innovative learning material with project based learning has successfully conducted for AcidBase Equilibrium topic. The subjects consisted of six sub topic with eight projects that can be conducted in an allocated time table. Implementation of an innovative learning materials with project is become a good strategy to help the students to gain the competence on chemistry. The learning material with projects provided the students with contextual and meaningful learning through engagement in active participation that improve the motivation in learning and simultaneously improve the knowledge and skills. Collaborative working among the students to do the project maximize their study potential that can transform their learning style moving from conventional learning to become student center learning that lead to improve students achievement.

\section{ACKNOWLEDGMENT}

Authors would like to acknowledge all lecturers of Analytical Chemistry in The Department of Chemistry Universitas Negeri Medan for their help in the study. This work was supported by Directorate Research and Community Service, Directorate General Strengthen Research and Development, Ministry of Research, Technology and Higher Education of the Republic of Indonesia, Under Tim Pascasarjana, No. 073/SP2H/LT/DRPM/2018.

\section{REFERENCES}

[1]. Adams, S., de Castro, P., Echenique, P., Estrada, J., Hanwell, M.D., Murray-Rust, P., Sherwood, P., Thomas, J., and Townsend, J., (2011), The Quixote project: Collaborative and Open Quantum Chemistry data management in the Internet age, Journal of Cheminformatics 3: 38 (27 pages), http://www.jcheminf.com/content/3/1/38.

[2]. Azer, S.A., Hasanato, R., Al-Nassar, S., Somily, A., dan AlSaad, M.M., (2013), Introducing integrated laboratory classes in a PBL curriculum: impact on student's learning and satisfaction, BMC Medical Education 13: 71-83.

[3]. Howe, E.M., (2009), A Method for Curriculum Development, The American Biology Teacher 71(7): 397-404.

[4]. Fiksl, M., Flogie, A., \& Aberšek, B. (2017). Innovative teaching/learning methods to improve science, technology and engineering classroom climate and interest, Journal of Baltic Science Education, 16(6): 1009-1019. 
[5]. Situmorang, M., Sinaga, M., Tobing, A.M.L., Sitorus, C.J., dan Tarigan, D.A., (2010), Teaching Innovation in the Laboratory to Increase Student's Achievement in Chemistry, Jurnal Penelitian Bidang Pendidikan 17(1): 7-14

[6]. Goto, K., Pelto, H., Pelletier, D.L., dan Tiffany, J.S., (2010), "It Really Opened My Eyes:" The Effect on Youth Peer Educators of Participating in an Action Research Project, Human Organization 69(2): 192-200.

[7]. Situmorang, M., Sinaga, M., Purba, J., Daulay, S.I., Simorangkir, M., Sitorus, M., and Sudrajat, A., (2018), Implementation of Innovative Chemistry Learning Material With Guided Tasks to Improve Students' Competence, Journal of Baltic Science Education. 17(4): 535-550.

[8]. Purba, J., and Situmorang, M., (2016), Inovasi Pembelajaran Berbasis Proyek Untuk Pengajaran Senyawa Enolat Pada Mata Kuliah Kimia Organik Lanjut [Learning innovation with project on the teaching of enolate compounds on advance organic chemistry ], Prosiding Seminar Nasional dan Rapat Tahunan BKS PTN-B bidang MIPA di Universitas Sriwijaya Palembang Tgl 22-24 Mei 2016.

[9]. Jahangiri, M., \& Hajian, R. (2013). Creative chemistry teaching, Asian Journal of Chemistry, 25(1), 377-380.

[10]. Lee, P.C., Lin, C.T., \& Kang, H.H. (2015). The influence of open innovative teaching approach toward student satisfaction: A case of $\mathrm{Si}-$ Men Primary School, Qual Quant, 2015: 1-17.

[11]. Herron, J.D., (1996), The Chemistry Classroom: Formulas for Succesful Teaching, American Chemical Society: Washington, DC.

[12]. Situmorang, M., Suyanti, R.D., Simatupang, N.I., dan Munthe, S.D.D. (2013), Pengembangan Buku Ajar Kimia SMA/MA Kelas X Sesuai Kurikulum 2013 Melalui Inovasi Pembelajaran Untuk Meningkatkan Hasil Belajar Siswa. Prosiding Seminar Hasil Penelitian Lembaga Penelitian Unimed Tahun 2013 Bidang Pendidikan, Tgl 14-16 November 2013, pp. 1-8.

[13]. Mahdjoubi, L., \& A-Rahman, M. A. (2012). Effects of multimedia characteristics on novice CAD learners' practice performance. Architectural Engineering and Design Management, 8(3): 214-225.

[14]. Huang, S.P., (2018), Effects of Innovative Education on Innovation Capability and Organizational Performance in High-Tech Industry, Eurasia Journal of Mathematics, Science \& Technology Education 14(3): 777-784

[15]. Siew, N.M., Amir, N., and Chong, C.L., (2015), The perceptions of preservice and in-service teachers regarding a project-based STEM approach to teaching science, Springer Plus 4: 8 (20 pages), http://www.springerplus.com/content/4/1/8.

[16]. Sheng, T. and Hu, Q., (2012), Human Extracellular Superoxide Dismutase Recombination: a Project Based Learning Program in Biochemistry Designed for Nursing Students, Asian J. Nursing Edu. and Research 2(3): 135-139.

[17]. Atasoy, B.M., Sarikaya, O., Kuscu, M.K., Yondem, M., Buyukkara, E., Eken, E.G., and Kahyaoglu, F., (2012), Students Meeting with Caregivers of Cancer Patient: Results of an Experience-Based Learning Project, J Canc Educ 27: 656-663. DOI 10.1007/s13187-012-0387-3.

[18]. Kemendikbud. 2014. Buku Kurikulum Pendidikan Tinggi. Jakarta: Direktorat Jendral Pendidikan Tinggi.

[19]. Robinson, J. K. (2013). Project-based learning: improving student engagement and performance in the laboratory. Analytical and Bioanalytical Chemistry, 405(1), 7-13.

[20]. Ellinas, C., Allan, N., Durugbo, C., and Johansson, A., (2015), How Robust Is Your Project? From Local Failures to Global Catastrophes: A Complex Networks Approach to Project Systemic Risk, PLOS ONE, (21 pages), DOI:10.1371/journal.pone.0142469.
[21]. Hosler, J., dan Boomer, K.B. (2011), Are Comic Books an EffectiveWay to Engage Nonmajors in Learning and Appreciating Science?. CBE-Life Sciences Education. 10: 309-317.

[22]. Yusfiani, M., dan Situmorang, M. (2011), Pengembangan dan Standarisasi Buku Ajar Kimia SMA/MA Kelas XII Semester I Berdasarkan Standar Isi KTSP. Jurnal Penelitian Bidang Pendidikan. 17(1): $36-45$.

[23]. Simatupang, N.I., dan Situmorang, M. Innovation Of Senior High School Chemistry Textbook To Improve Students Achievement In Chemistry. 2013. Proceeding of The 2nd International Conference of the Indonesian Chemical Society 2013 October, 22-23 ${ }^{\text {th }} 2013$, pp. 44-52.

[24]. Situmorang, M., Sitorus, M., dan Situmorang, Z., (2015), Pengembangan Bahan Ajar Kimia SMA/MA Inovatif dan Interaktif Berbasis Multimedia, Prosiding Semirata 2015 Bidang MIPA BKS-PTN Barat, Universitas Tanjungpura Pontianak.

[25]. Situmorang, M. dan Sinaga, M. (2006), Inovasi Pembelajaran Pada Mata Kuliah Kimia Analitik II. Jurnal Pendidikan Matematika dan Sain. 1(2): 114-119.

[26]. Situmorang, M., Sitorus, M., Hutabarat, W., and Situmorang, Z., (2015), The Development of Innovative Chemistry Learning Material for Bilingual Senior High School Students in Indonesia, International Educational Studies. 8(10), 72-85

[27]. Borg, W.R., and Gall, M.D., (1983), Educational Research: An Introduction (4ed), Longman, Newyork and London.

[28]. Situmorang, M., (2013), Kimia Analitik I (Dasar Kimia Analitik), FMIPA Unimed Press, Medan, Indonesia.

[29]. UNIMED, (2016). Kurikulum Berorientasi Kerangka Kualifikasi Nasional Indonesia (KKNI), Indonesian National Qualifications Framework Curriculum, Universitas Negeri Medan, Medan, Indonesia.

[30]. Situmorang, M., Sinaga, M., Purba, J., Daulay, S.I., Simorangkir, M., Sitorus, M., and Sudrajat, A., (2018), Implementation of Innovative Chemistry Learning Material With Guided Tasks to Improve Students' Competence, Journal of Baltic Science Education. 17(4): 535-550.

[31]. Purba, J., and Situmorang, M., (2016), Inovasi Pembelajaran Berbasis Proyek Untuk Pengajaran Senyawa Enolat Pada Mata Kuliah Kimia Organik Lanjut [Learning innovation with project on the teaching of enolate compounds on advance organic chemistry ], Prosiding Seminar Nasional dan Rapat Tahunan BKS PTN-B bidang MIPA di Universitas Sriwijaya Palembang Tgl 22-24 Mei 2016.

[32]. Skoog, D.A., West, D.M., Holler, F.J. \& Crouch, S.R. (2013) Fundamentals of Analytical Chemistry, 9th ed., international ed. Brooks/Cole, Cengage Learning.

[33]. Harris, D.C. (2015). Quantitative Chemical Analysis, 9th ed., New York: W.H. Freeman and Company.

[34]. Ofstad, W., dan Brunner, L.J., (2013), Team-Based Learning in Pharmacy Education, American Journal of Pharmaceutical Education 77(4): 1-11 (Article 70).

[35]. Gubacs, K., (2004), Project-based Learning: A Student-centered Approach to Integrating technology into Physical Education Teacher Education, Journal of Physical Education, Recreation \& Dance 75(7): $33-43$.

[36]. Tan, J.C.L., and Chapman, A., (2016), Project-Based Learning for Academically-Able Student, Sense Publishers, Rotherdam, The Netherlands. 